\title{
PROMOTING HEALTHY SNACKS TO ELEMENTARY SCHOOLS CHILDREN USING ANIMATED CARTOON IN TEBET, SOUTH JAKARTA
}

\author{
Nindy SABRINA and Khoirul ANWAR \\ Nutrition Study Program, Sahid University Jakarta, Indonesia \\ sabrina.nindy@gmail.com
}

\begin{abstract}
Based on elementary school's environmental observations, there is still much consumption of unhealthy snacks among children, especially in Jakarta. This program aims to increase healthy snacks knowledge for elementary school students at SDN Menteng Dalam 07 Pagi and SDN Menteng Dalam 05 Pagi, Tebet District, South Jakarta. The method used was the provision of education through watching cartoons about eating healthy snacks. The students were excited when watching cartoons for 30 minutes. Students were also measured for height and weighed to determine their nutritional status based on BMI/Age index. Knowledge improvement was evaluated by giving pre and post test questionnaires. The results showed a significant increase in knowledge between before and after watching cartoons. Animated cartoons can be used to promote healthy snacks among primary school students.
\end{abstract}

\section{Keywords: Nutrition Education, Healthy Snacks, Elementary School Children, Nutritional Status, Animated Cartoon}

\section{BACKGROUND}

Health can affect the quality of human resources in the future (Burhani, Oenzil, \& Revilla, 2016). Safe and nutritious food consumption becomes a factor that affects the nutritional status and health of children. Nutrition in school-age children needs to be considered because it will also affect the health status of the next age group. Children who are overweight and obese tend to have a similar body image as adults who will risk developing non-communicable diseases such as diabetes (Sahoo et al., 2015). In addition, if a child experiences a poor nutritional status such as stunting or wasting, it will also affect their productivity such as decreased learning ability that impacts their achievement at school (Sa'adah, Herman, \& Sastri, 2014).

In the study of Anggiruling et al., The year 2019 shows a relationship between the selection of children's snacks on the nutritional status of school children (Anggiruling et al., 2019). Research conducted at an elementary school in Gorontalo Regency showed that there was a relationship between students who had a snack habit and the nutritional status of obesity (Nuryani \& Rahmawati, 2018). The high frequency of snacks affects the increased energy intake in children. Frequent snacking may occur because of the habits of children who skip breakfast (Mariza \& Kusumastuti, 2013).

Elementary school children aged 7-11 years experience cognitive development. They can think logically and begin to distinguish whether their actions are good or bad (Piaget, 1932). Parents act as primary educators in the family, influencing the children's e thinking development and affecting children's snack preferences (Permono, 2013). While at school, teachers are the primary educators who provide insight and guidance to children through teaching and learning activities to develop students' character (Sutisna, Indraswati, \& Sobri, 2019). However, not all teachers have a health education background. The teachers need to focus more on choosing educational resources and knowing how to deliver them to students to promote nutrition and health education.
Therefore, it will be easier for children to understand.

In the school environment, there are some harmful ingredients found in children's snacks. In 2014, the Food and Drug Supervisory Agency (BPOM) found that $23.28 \%$ of snack samples from 13,500 elementary schools (SD) or Madrasah Ibtidaiyah (MI) did not meet food safety requirements due to microbial contamination, food additives, and the use of harmful ingredients $(R$. Kemenkes, 2014). Sample of food sold in front of elementary schools in Bantul showed that out of 98 food, $15.3 \%$ were proven to contain borax, and $25.5 \%$ were proven to contain formaldehyde (Paratmanitya \& Aprilia, 2016). Not only food, but research in Medan Johor also showed that $72.7 \%$ of beverage sellers in front of schools used saccharin and cyclamate in the drinks they sold (Sitorus, 2016)

Based on observations at SDN Menteng Dalam 07 Pagi and SDN Menteng Dalam 05 Pagi during breaks and after school, students were seen buying brightly colored foods, high-density energy, and low nutrients. Students did not seem to know that snacks' seller handling, the packaging used, the ingredients used, and the way of processing food will affect the food hygiene. This may happen because of a lack of student's knowledge about healthy snacks. The school has tried to suggest to the students not to buy food from outside. However, maybe because the teacher's educational background is not from health, then what the teacher explains to students may not be properly understood and applied. Providing health education for primary age children requires special skills and appropriate media so that children can easily understand it. The purpose of this community service is to assist the schools in increasing students' knowledge about food safety at the elementary school level so that children can opt for healthy snacks.

\section{METHOD}

The target of community services were grade 3, grade 4, and grade 5 elementary school students at SDN Menteng Dalam 07 Pagi and SDN Menteng Dalam 05 
Pagi. From SDN Menteng Dalam 07 Pagi, there were 108 students as participants while 104 students from SDN Menteng Dalam 05 Pagi.

The steps taken were mapping the school problems faced by discussing with teachers at the school, observing student behavior, and observing environmental conditions. The preparation of the activity begins with determining the activity date, activity objectives, location, number of students, the role of the school, and planning the evaluation process. Furthermore, we checked school facilities, education media and materials, and anthropometric measurements tools. Question papers about healthy snacks were given to students before the education activity to determine students' basic knowledge.

Healthy snacks education material was presented as cartoons that are shown in class. The animated cartoon explains the characteristics and examples of healthy snacks. The animated cartoon also illustrates the effects of eating unhealthy snacks. There were two animated cartoon titles shown, namely "3D Animation of Healthy Snacks for Cita" produced by Baba Studio, and the video "Pompi Volume 1: The Effects of Eating Unhealthy Food" produced by BPOM Aceh. The total video playback time is 30 minutes. After that, to evaluate the results of the education, a post-test was conducted. In addition, we asked some students to come forward to tell the content of the cartoon.

After giving the education and asking questions in class, students were also measured for their height using a microtoise and weighed using a calibrated analog scale. Height and weight were measured to determine the nutritional status of students. Moreover, the students can hand the result of the measurement to their parents. Determination of children's nutritional status based on BMI/age index. The nutritional status category is based on the regulation of the Minister of Health of the Republic of Indonesia No. 2 of 2020 concerning child anthropometry standards.

\section{RESULTS AND DISCUSSION}

The implementation of community service activities at SDN Menteng Dalam 07 Pagi and SDN Menteng Dalam 05 Pagi, Tebet, South Jakarta was carried out in June 2019. Initial observations at SDN Menteng Dalam 07 Pagi showed one canteen located near the school gate consisting of three stands (Figure 1a). However, only two booths made buying and selling transactions. With the limited and small number of canteen stands, many students jostle to purchase food. The two strands look clean and sell food that conforms to the healthy snack standards. However, due to the limited number of vendors, and the large number of students taking breaks at the same time, some students decide to buy snacks outside. Even though the school closed the gate and has warned that buying snacks outside is not allowed, the students and sellers in front of the entrance can still make transactions through the school fence (Figure 1b). The school cannot prevent street food vendors in front of the school and needs help to make students aware of the importance of choosing healthy snacks.

Unlike SDN Menteng Dalam 07 Pagi, at SDN Menteng Dalam 05 Pagi, students seem to be free to enter and exit the school area because the school has a wideopen fence.In front of the school, there are also stalls selling snacks that are permanently built. Moreover, street food vendors always present during breaks and after school. Meanwhile, the school canteen was not visible at the time of the initial observation. Students buy snacks outside of school during breaks and after school and there seems to be no prohibition from the school. Not only students, but many parents also buy snacks outside the school when they pick up their children as shown in Figure 2a.
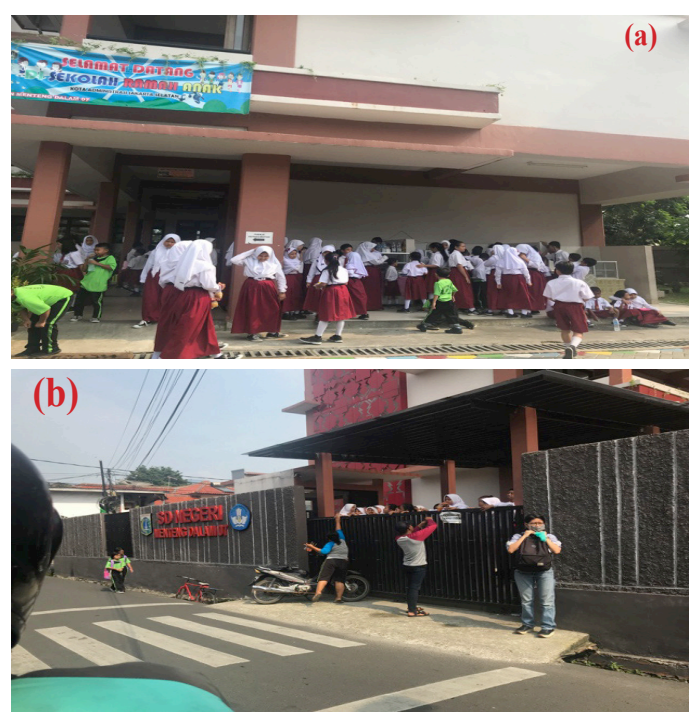

Figure 1. (a) Students Jostle Purchasing Food in School's Canteen, \& (b) The Street Food Vendors Are Passing the Food Over the Fence

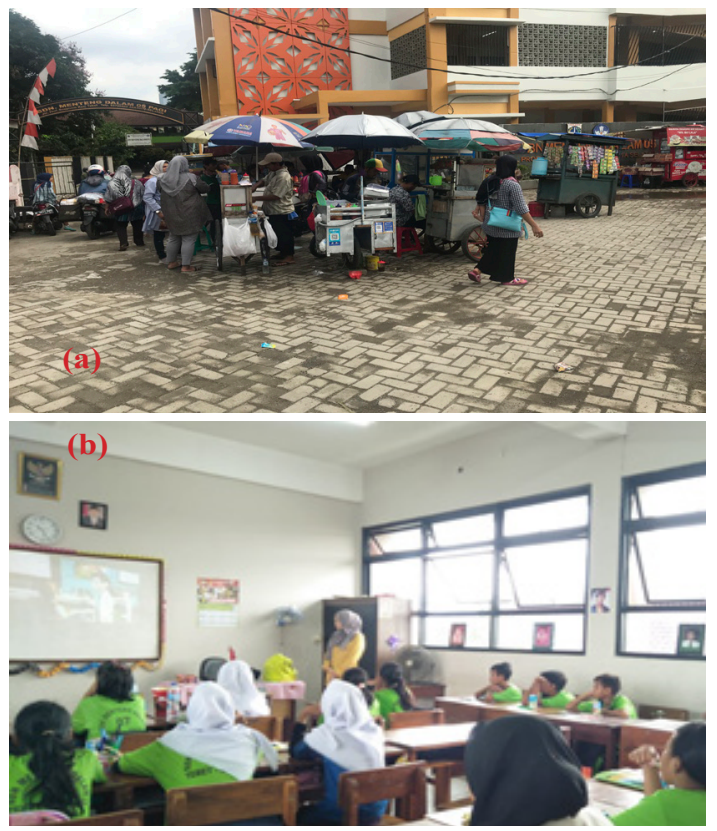

Figure 2. (a) Food Vendors in front of School Gate, \& (b) Students watched the education cartoons 
The implementation of the healthy snack education was running smoothly with the support of the school. Healthy snack materials was given to students in grades 3 , 4 , and 5 because students are considered fluent in reading and writing at that age, so they can answer pre-test and post-test questions well. The material given, titled "3D Animation of Healthy Snacks for Cita", tells about a child who got a stomachache when buying snacks outside. The child experiences vomiting and diarrhea because the food is not only not hygienic, but it also contains harmful substance such as artificial sweeteners, preservatives (borax, formalin), and rhodamine B. In addition, the second video tells a story about a child who got diarrhea due to snacking carelessly. The students seemed interested and seriously watched the cartoons displayed on the LCD (Figure 2b).

To figure out students' basic knowledge, a pre-test about healthy snacks was given before giving education. The questions presented were related to the characteristics of hygiene and safe food and the consequences if children snacked carelessly. After watching the animated cartoon, the post-test process was carried out. The result of the pretest and post-test scores in the Table 1 explains that there is a significant increase before and after receiving education. This result is similar with research conducted by Sakamoto et al., in children aged 10-11 years, showing a significant increase in children's knowledge about specific diseases after being given education through animated cartoons and manga (Sakamoto et al., 2014). In addition, 179 students in Athens, Greece, also found that it was easier to understand certain natural science concepts when studying them by watching animated cartoons which is usually difficult to understand (Dalacosta, Kamariotaki-Paparrigopoulou, Palyvos, \& Spyrellis, 2009). Kausar (2013) also explains that audio-visual media can replace the boring teaching and learning process to be more fun (Kausar, 2013). Cartoon media is considered more effective and sustainable in providing health education compared than conventional methods (Sinor, Utama, \& Indah, 2011).

Health education for early childhood is needed so that children have healthy living habits in the future that will contribute to their quality of life (Jara Baraybar Alvarenga de Oliveira et al., 2020). Research in Leeds (UK) shows that frequent health education is more effective in changing the behavior of respondents than those who only receive education once (Kowash, Pinfield, Smith, \& Curzon, 2000). In addition, the combination of parents' involvement and health education curriculum at school may result in positive outcomes (Manios \& Kafatos, 1999).

After delivering the education material, anthropometric measurements were carried out in the place provided. Children line up to be weighed and measured their height. The results of weight and height can be used to determine the nutritional status of children aged 5-18 years using the body mass index according to age
(Kemenkes, 2020; Organization, 2006). Figure 3 shows that $8 \%$ students are under nutrition while $22 \%$ students are over nutrition. This result indicates that we still have a task to help the children to get normal nutritional status by giving them nutrition education.

Table 1. Pupils' avarage points before and after education

\begin{tabular}{lll}
\hline \multicolumn{1}{c}{ Knowledge } & \multicolumn{1}{c}{ Mean \pm SD } & p-value \\
\hline Pre-test & $9.16 \pm 1.83$ & 0.01 \\
Post-test & $9.48 \pm 1.61$ & \\
\hline
\end{tabular}

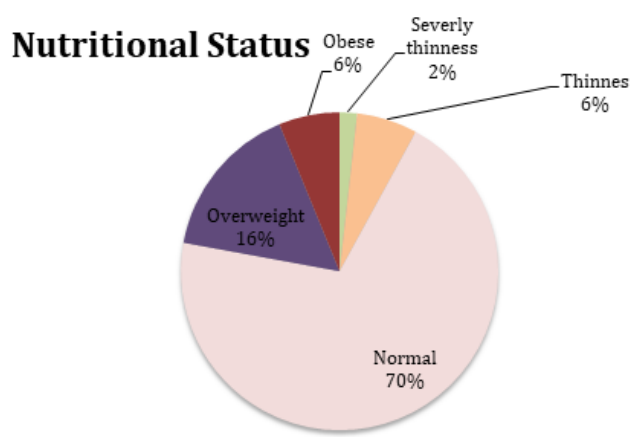

Figure 3. Nutritional Status Precentage of children.

To conclude, promoting healthy snacks education using animated cartoon media effectively increases students' knowledge as evidenced by the increase in the post-test scores. It is necessary to provide regular education to students so that students' habits of eating healthy snacks stick to them.

\section{ACKNOWLEDGMENT}

We would like to thank LPPM Sahid University for providing grants for this activity through an internal Sahid University grant in 2019. We also thank SDN Menteng Dalam 07 Pagi and SDN Menteng Dalam 05 Pagi, Tebet, South Jakarta who are willing to be our partners.

\section{REFERENCES}

Anggiruling, D. O., Ekayanti, I., Khomsan, A., Masyarakat, D., Manusia, F., \& Bogor, I. (2019). “Analisis Faktor Pemilihan Jajanan, Kontribusi Gizi Dan Status Gizi Siswa Sekolah Dasar Factors Analysis Of Snack Choice, Nutrition Contribution And Nutritional Status Of Primary School Children". Jurnal Mkmi, 15(1), 81-90.

Burhani, P.A., Oenzil, F., \& Revilla, G. (2016). "Hubungan Tingkat Pengetahuan Ibu Dan Tingkat Ekonomi Keluarga Nelayan Dengan Status Gizi Balita Di Kelurahan Air Tawar Barat Kota Padang". Jurnal Kesehatan Andalas, 5(3).

Dalacosta, K., Kamariotaki-Paparrigopoulou, M., Palyvos, J. A., \& Spyrellis, N. (2009). "Multimedia Application With Animated Cartoons For Teaching Science In Elementary Education". Computers \& Education, 52(4), 741-748. Doi:Https://Doi. Org/10.1016/J.Compedu.2008.11.018 
Jara Baraybar Alvarenga De Oliveira,A.,Albertini Reis, B., Fedrigo, B., Souza Vasconcellos, G., Bertaglia, L., Espinosa, M. V., .. . Moreira, A. (2020). “Importance OfHealth Education Actions To Improve Quality Of Life Of Vulnerable Populations". European Journal Of Public Health, 30(Supplement_5). Doi:10.1093/ Eurpub/Ckaa166.468

Kausar, G. (2013). "Students' Perspective Of The Use Of Audio Visual Aids In Pakistan". International Proceedings Of Economics Development And Research, 68, 11.

Ministry Of Health Regulation On Child Anthropometry Standars, (2020).

Kemenkes, R. (2014). "Situasi Pangan Jajanan Anak Sekolah". Infodatin Pusat Data Dan Informasi Kemenkes Ri.

Kowash, M. B., Pinfield, A., Smith, J., \& Curzon, M. E. J. (2000). "Effectiveness On Oral Health Of A LongTerm Health Education Programme For Mothers With Young Children". British Dental Journal, 188(4), 201-205. Doi:10.1038/Sj.Bdj.4800431

Manios, Y., \& Kafatos, A. (1999). "Health And Nutrition Education In Elementary Schools: Changes In Health Knowledge, Nutrient Intakes And Physical Activity Over A Six Year Period". Public Health Nutrition, 2, 445-448. Doi:10.1017/S1368980099000610

Mariza, Y. Y., \& Kusumastuti, A. C. (2013). Hubungan Antara Kebiasaan Sarapan Dan Kebiasaan Jajan Dengan Status Gizi Pada Anak Sekolah Dasar Di Kecamatan Pedurungan Kota Semarang. Diponegoro University.

Nuryani, N., \& Rahmawati, R. (2018). 'Kebiasaan Jajan Berhubungan Dengan Status Gizi Siswa Anak Sekolah Di Kabupaten Gorontalo". Jurnal Gizi Indonesia (The Indonesian Journal Of Nutrition), 6(2), 114-122.

Organization, W. H. (2006). Who Child Growth Standards: Length/Height-For-Age, Weight-For-Age, WeightFor-Length, Weight-For-Height And Body Mass Index-For-Age: Methods And Development: World Health Organization.
Paratmanitya, Y., \& Aprilia, V. (2016). “Kandungan Bahan Tambahan Pangan Berbahaya Pada Makanan Jajanan Anak Sekolah Dasar Di Kabupaten Bantul". Jurnal Gizi Dan Dietetik Indonesia (Indonesian Journal Of Nutrition And Dietetics), 4(1), 49-55.

Permono, H. (2013). "Peran Orangtua Dalam Optimalisasi Tumbuh Kembang Anak Untuk Membangun Karakter Anak Usia Dini”.

Piaget, J. (1932). The Moral Development Of The Child: London: Kegan Paul.

Sa'adah, R. H., Herman, R. B., \& Sastri, S. (2014). "Hubungan Status Gizi Dengan Prestasi Belajar Siswa Sekolah Dasar Negeri 01 Guguk Malintang Kota Padangpanjang”. Jurnal Kesehatan Andalas, 3(3).

Sahoo, K., Sahoo, B., Choudhury, A. K., Sofi, N. Y., Kumar, R., \& Bhadoria, A. S. (2015). "Childhood Obesity: Causes And Consequences”. Journal of Family Medicine And Primary Care, 4(2), 187.

Sakamoto, Y., Yokota, C., Miyashita, F., Amano, T., Shigehatake, Y., Oyama, S., ... Minematsu, K. (2014). "Effects Of Stroke Education Using An Animated Cartoon And A Manga On Elementary School Children". Journal Of Stroke And Cerebrovascular Diseases, 23(7), 1877-1881. Doi:Https://Doi. Org/10.1016/J.Jstrokecerebrovasdis.2014.02.015

Sinor, M. Z., Utama, P., \& Indah, P. (2011). Comparison Between Conventional Health Promotion And Use Of Cartoon Animation In Delivering Oral Health Education.

Sitorus, E. N. (2016). "Hubungan Karakteristik Dan Perilaku Pedagang Dengan Keberadaan Pemanis Sakarin Dan Siklamat Dalam Minuman Sirup Pada Sekolah Dasar (Sd) Di Kecamatan Medan Johor Tahun 2014”. Jurnal Farmanesia, 3(1), 24-34.

Sutisna, D., Indraswati, D., \& Sobri, M. (2019). "Keteladanan Guru Sebagai Sarana Penerapan Pendidikan Karakter Siswa". Jpdi (Jurnal Pendidikan Dasar Indonesia), 4(2), 29-33. 